\title{
Grape seed extract triggers apoptosis in Caco-2 human colon cancer cells through reactive oxygen species and calcium increase: extracellular signal-regulated kinase involvement
}

\author{
Simona Dinicola ${ }^{1,2}$, Maria Addolorata Mariggio ${ }^{3}$, Caterina Morabito ${ }^{3}$, Simone Guarnieri ${ }^{3}$, \\ Alessandra Cucina ${ }^{2}$, Alessia Pasqualato ${ }^{2,3}$, Fabrizio D'Anselmi ${ }^{2,4}$, Sara Proietti ${ }^{1,2}$, \\ Pierpaolo Coluccia ${ }^{2}$ and Mariano Bizzarri ${ }^{5 *}$ \\ ${ }^{1}$ Department of Clinical and Molecular Medicine, Piazza Sassari 3, La Sapienza University, 00161 Rome, Italy \\ ${ }^{2}$ Department of Surgery "Pietro Valdoni", Via A. Scarpa 14, La Sapienza University, 00161 Rome, Italy \\ ${ }^{3}$ Department of Neuroscience and Imaging - CeSI, Via dei Vestini 31, University "G. d'Annunzio", 66100 Chieti, Italy \\ ${ }^{4}$ Italian Space Agency, Viale Liegi 26, 00198 Rome, Italy \\ ${ }^{5}$ Department of Experimental Medicine, Viale Regina Elena 324, La Sapienza University, 00161 Rome, Italy
}

(Submitted 25 May 2012 - Final revision received 12 December 2012 - Accepted 12 December 2012 - First published online 25 February 2013)

\section{Abstract}

Grape seed extract (GSE) from Italia, Palieri and Red Globe cultivars inhibits cell growth and induces apoptosis in Caco-2 human colon cancer cells in a dose-dependent manner. In order to investigate the mechanism(s) supporting the apoptotic process, we analysed reactive oxygen species (ROS) production, intracellular $\mathrm{Ca}^{2+}$ handling and extracellular signal-regulated kinase (ERK) activation. Upon exposure to GSE, ROS and intracellular $\mathrm{Ca}^{2+}$ levels increased in Caco-2 cells, concomitantly with ERK inactivation. As ERK activity is thought to be essential for promoting survival pathways, inhibition of this kinase is likely to play a relevant role in GSE-mediated anticancer effects. Indeed, pretreatment with $\mathrm{N}$-acetyl cysteine, a ROS scavenger, reversed GSE-induced apoptosis, and promoted ERK phosphorylation. This effect was strengthened by ethylene glycol tetraacetic acid-mediated inhibition of extracellular $\mathrm{Ca}^{2+}{ }_{\text {influx. }} \mathrm{ROS}$ and $\mathrm{Ca}^{2+}{ }_{\text {influx inhi- }}$ bition, in turn, increased ERK phosphorylation, and hence almost entirely suppressed GSE-mediated apoptosis. These data suggested that GSE triggers a previously unrecognised ERK-based mechanism, involving both ROS production and intracellular $\mathrm{Ca}^{2+}$ increase, eventually leading to apoptosis in cancer cells.

\section{Key words: Grape seed extract: Apoptosis: Reactive oxygen species: Intracellular $\mathrm{Ca}^{2+}$ : Extracellular signal-regulated kinase}

Colon cancer is one of the major causes of cancer-related mortality in both men and women worldwide ${ }^{(1)}$. Epidemiological studies have shown that dietary custom is among the leading causes of colon cancer in Western society ${ }^{(2)}$. In addition, compelling evidence has been provided demonstrating that several flavonoid-rich foods could display relevant cancer-preventive effects. Thus, the isolation and characterisation of potential chemopreventive agents in fruits and vegetables have represented a major task in anticancer studies ${ }^{(3)}$.

Grape seed extract (GSE) contains several active substances - such as epigallocatechins, anthocyanins, gallic acid and so forth - which have shown promising chemopreventive and/ or anticancer efficacy in various cell cultures and animal models ${ }^{(4,5)}$
GSE-based anticancer effects are generally ascribed to its antioxidant and/or scavenging effects, enabling cells to prevent macromolecule damage induced by free radical compounds ${ }^{(6,7)}$.

In addition, procyanidins and epigallocatechins have proven to be cytotoxic towards human breast, lung and gastric adenocarcinoma cells, while enhancing the growth and viability of normal human gastric mucosal cells ${ }^{(6)}$.

Indeed, GSE from Italia, Palieri and Red Globe cultivars significantly inhibits growth rate and induced apoptosis in Caco2 human colon cancer cells, via apoptosis-inducing factor and caspase-dependent pathways $^{(8)}$. Yet, the detailed molecular mechanism of GSE-induced apoptosis in Caco-2 cells has not yet been elucidated.

Abbreviations: EGTA, ethylene glycol tetraacetic acid; ERK, extracellular signal-regulated kinase; GSE, grape seed extract; $\mathrm{H}_{2} \mathrm{DCF}-\mathrm{DA}$, dichlorodihydrofluorescein diacetate; JC-1, 5, ' $, 6,6^{\prime}$-tetrachloro-1,1',3,3'- tetraethylbenzimidazolylcarbocyanine iodide/chloride; MAPK, mitogen-activated protein kinase; NAC, $N$-acetyl cysteine; NES, normal external solution; ROS, reactive oxygen species.

*Corresponding author: M. Bizzarri, fax + 39 649766897, email mariano.bizzarri@uniroma1.it 
Mounting evidence supports a physiological role for reactive oxygen species (ROS) as a 'second messenger' in the intracellular signalling cascade that controls cell growth, proliferation, migration and apoptosis ${ }^{(9)}$, and, interestingly, ROS can activate mitogen-activated protein kinase (MAPK) pathways ${ }^{(10)}$. Even intracellular $\mathrm{Ca}^{2+}$ and its association with mitochondrial function/dysfunction may mediate the involvement of $\mathrm{MAPK}^{(11)}$

A large number of natural compounds, derived from plants and animals, such as the alkaloid berberine, notexin (derived from snake venom), panaxydol from ginseng roots, tocotrienols (members of the vitamin E family), have been shown to induce apoptosis in cancer cell lines involving a complex intracellular crosstalking that included ROS production, intracellular $\mathrm{Ca}^{2+}$ fluxes and the modulation of mitochondrial functional activity as well as MAPK activation ${ }^{(11-14)}$.

We therefore investigated cellular targets involved in the mechanism underlying early apoptotic processes triggered by GSE on Caco-2 cells. Namely, ROS levels were studied after stimulation with GSE obtained from different cultivars, and characterised by a different quantitative composition of flavan-3-ols (epigallocatechins and procyanidins). Apoptosis was further correlated with ROS production and mitochondrial membrane potential, and subsequently with $\mathrm{Ca}^{2+}$ flux changes. ROS-dependent apoptotic effects were dynamically recorded in the presence and absence of a ROS scavenger drug ( $N$-acetyl cysteine, NAC). In turn, $\mathrm{Ca}^{2+}$-dependent programmed cell death was studied in the presence or absence of a Ca chelator (ethylene glycol tetraacetic acid, EGTA). Eventually, the involvement of extracellular signal-regulated kinase (ERK) phosphorylation status change was investigated during GSE stimulation, by inhibiting both ROS production and $\mathrm{Ca}^{2+}$ fluxes, in order to ascertain the contribution of the aforementioned processes to cancer cell apoptosis.

\section{Experimental methods}

\section{Cell cultures}

The undifferentiated and tumorigenic human colorectal cancer cell lines Caco-2 and HCT-8 were obtained from the European Collection of Cell Cultures. Primary human colon fibroblasts were isolated from a healthy biopsy by collagenase type II digestion. Cells were grown in Dulbecco's modified Eagle's medium supplemented with $10 \%$ fetal calf serum and antibiotics (penicillin $100 \mathrm{IU} / \mathrm{ml}$, streptomycin $100 \mu \mathrm{g} / \mathrm{ml}$ and gentamicin $200 \mu \mathrm{g} / \mathrm{ml}$ ). The cultures were kept at $37^{\circ} \mathrm{C}$ in an atmosphere of $5 \% \mathrm{CO}_{2}$ in air and the medium was changed every 3rd day. At confluence, the cells were subcultured after removal with $0.05 \%$ trypsin-0.01\% EDTA. Caco-2 cells were maintained at low density and trypsinised before reaching confluence to avoid differentiation.

\section{Grape seed extract preparation}

Italia white grape, Palieri and Red Globe red grape cultivars from the experimental vineyard located in the Puglia region (Italy) were kindly provided by the Agricultural Research
Council - Research Unit for grape and winegrowing in the Mediterranean environment (CRA-UTV). Fresh grape berry samples were skinned and seeds were separated from pulp and then gently wiped with filter paper to eliminate pulp residues. Homogeneous and dry material from seeds was obtained, extracted with methanol, purified and analysed by electrospray ionisation-MS according to a previously published method ${ }^{(15)}$. The three cultivars showed significant differences with respect to their composition: Italia GSE contained $2.5 \mathrm{mg} / \mathrm{g}$ catechins and $4.1 \mathrm{mg} / \mathrm{g}$ procyanidins; Palieri GSE contained $6.2 \mathrm{mg} / \mathrm{g}$ catechins and $5.6 \mathrm{mg} / \mathrm{g}$ procyanidins; Red Globe GSE contained $3.9 \mathrm{mg} / \mathrm{g}$ catechins and $3.9 \mathrm{mg} / \mathrm{g}$ procyanidins ${ }^{(15)}$. GSE was resuspended in $70 \%$ ethanol at a concentration of $30 \mathrm{mg} / \mathrm{ml}$ and stored in the dark at $-20^{\circ} \mathrm{C}$. With the intention of obtaining the concentration of $100 \mu \mathrm{g} /$ $\mathrm{ml}$ (the highest concentration of GSE used in the present experiment), GSE stock solutions were diluted 1:300.

\section{Apoptotic cell death assay}

Caco-2 cells were cultured at confluence into $25 \mathrm{~cm}^{2}$ flasks (Falcon; Becton Dickinson Labware) in a standard medium and stimulated with $70 \%$ ethanol (1:300, control) or with Italia, Palieri or Red Globe GSE at $100 \mu \mathrm{g} / \mathrm{ml}$ and incubated at $37^{\circ} \mathrm{C}$ in an atmosphere of $5 \% \mathrm{CO}_{2}$ in air. After 3 and $24 \mathrm{~h}$, the cells were trypsinised, washed twice with PBS and stained with fluorescein isothiocyanate-labelled annexin $\mathrm{V}$ and 7-aminoactinomycin-D according to the manufacturer's instructions (Instrumental Pro3 Laboratory). Then, the samples were analysed by flow cytometry (EPICS Coulter XL; Beckman Coulter, Inc.) for the quantification of apoptotic cells. Fluorescence of 20000 events was measured and an excitation wavelength of $488 \mathrm{~nm}$ was used in combination with standard filters to discriminate between the fluorescence channels FL1 and FL3, forward scatter and side scatter. Where indicated, Caco-2 cells were also stimulated with GSE in the presence of $100 \mathrm{~mm}$ NAC (after pre-incubation with $100 \mathrm{~mm}-\mathrm{NAC}$ for $30 \mathrm{~min}$ ) or in a $\mathrm{Ca}^{2+}$-free PBS in the presence of $0.5 \mathrm{~mm}$-EGTA. In detail, cytometric analysis was performed after 3 and $24 \mathrm{~h}$ of GSE exposure in the presence of $100 \mathrm{~mm}-\mathrm{NAC}$ or after $1 \mathrm{~h}$ of GSE exposure in the presence of $0.5 \mathrm{~mm}$-EGTA in the $\mathrm{Ca}^{2+}$ free PBS. The same experiments were performed on HCT-8 cells and primary human colon fibroblasts. For each data point, three independent experiments were performed.

\section{Determination of reactive oxygen species production}

The accumulation of ROS in Caco-2 cells was measured using a modified version of the method described by Wang \& Joseph $^{(16)}$. Caco-2 cells were seeded $\left(5 \times 10^{3}\right.$ cells/well $)$ in growth medium into special-optics ninety-six-well plates (Corning Costar). Immediately before exposure to 25, 50 and $100 \mu \mathrm{g} / \mathrm{ml} \mathrm{GSE}$, cells were incubated for $40 \mathrm{~min}$ at $37^{\circ} \mathrm{C}$ in sterile normal external solution (NES: $140 \mathrm{~mm}-\mathrm{NaCl}$, $2.8 \mathrm{~mm}-\mathrm{KCl}, \quad 2 \mathrm{~mm}-\mathrm{CaCl}_{2}, \quad 2 \mathrm{~mm}-\mathrm{MgCl}_{2}, \quad 10 \mathrm{~mm}$-glucose and 10 mM-HEPES, pH 7.3) containing $10 \mu \mathrm{M}$-dichlorodihydrofluorescein diacetate ( $\mathrm{H}_{2} \mathrm{DCF}-\mathrm{DA} ;$ Molecular Probes). After incubating with $\mathrm{H}_{2}$ DCF-DA, the cells were rinsed with NES 
and exposed to GSE for 5 min. Fluorescence was measured using a microplate reader (SpectraMax Gemini XS; Molecular Devices), maintaining temperature at $25^{\circ} \mathrm{C}$. Excitation and emission filters were set at 490 and $520 \mathrm{~nm}$, respectively (bandwidth $\pm 15 \mathrm{~nm}$ ). Fluorescence was recorded from each well every $30 \mathrm{~s}$ for $5 \mathrm{~min}$ and acquired on a computer using SoftMax Pro (version 5.0; Molecular Devices). Fluorescence values for each sample are expressed as means with their standard errors of $f / f_{\mathrm{c}}$, where $f$ is the fluorescence value acquired in the treated samples and $f_{\mathrm{c}}$ is the fluorescence value acquired in the unexposed control samples. Where indicated, Caco-2 cells were also stimulated with GSE in the presence of $100 \mathrm{~mm}-\mathrm{NAC}$ (after pre-incubation with $100 \mathrm{~mm}-\mathrm{NAC}$ for $30 \mathrm{~min}$ ) or in a $\mathrm{Ca}^{2+}$-free NES in the presence of $0.5 \mathrm{~mm}$-EGTA. Then, the same fluorescence analyses were performed after GSE addition. The same experiments were performed on HCT-8 cells and primary human colon fibroblasts. For each experimental condition, eight repetitions were performed in three independent experiments ${ }^{(17)}$.

\section{Measurement of mitochondrial membrane potential}

Mitochondrial membrane potentials were determined using JC-1 (5, ' $, 6,6^{\prime}$-tetrachloro-1,1',3,3'- tetraethylbenzimidazolylcarbocyanine iodide/chloride; Molecular Probes), a cationic carbocyanine dye that accumulates in the mitochondria. When the transmembrane potential is high, as in normal cells, JC-1 forms dimers (J-aggregates) that emit red fluorescence. When the potential is low, an index of oxidative stress, the dye forms monomers that emit green fluorescence, and there is a concurrent decrease in red fluorescence. The red:green fluorescence ratio is dependent on the mitochondrial membrane potential and not on other factors (e.g. mitochondrial size, shape, density) that might influence single-component fluorescence signals.

Caco- 2 colon cancer cells were plated at $5 \times 10^{3}$ cells/well in special-optics ninety-six-well plates (Corning Costar) and, after adhesion, incubated without (controls) or with different stimuli $(25,50$ and $100 \mu \mathrm{g} / \mathrm{ml}$ of GSE) for different times ( $10 \mathrm{~min}, 1$ and $3 \mathrm{~h})$, as indicated in the Results section. At the end of incubation, the cells were incubated in growth medium containing $10 \mu \mathrm{g} / \mathrm{ml}$ of JC- 1 for $10 \mathrm{~min}$ at $37^{\circ} \mathrm{C}$. After three rinses with NES, the fluorescence of loaded cells was detected on a Gemini SpectraMax XS fluorescence plate reader (Molecular Devices) using an excitation wavelength of $485 \mathrm{~nm}$ and recording the emissions of the JC- 1 monomer and aggregate at 530 and $590 \mathrm{~nm}$, respectively. For each experiment, the aggregate:monomer (red:green) ratios were calculated. The values of fluorescence acquired from each sample are expressed as means with their standard errors of $f(\mathrm{r} / \mathrm{g}) / f_{\mathrm{c}}(\mathrm{r} / \mathrm{g})$, where $f(\mathrm{r} / \mathrm{g})$ is the red:green fluorescence value acquired in the treated samples and $f_{\mathrm{c}}(\mathrm{r} / \mathrm{g})$ is the red:green fluorescence value acquired in the unexposed control samples. Where indicated, Caco-2 cells were also stimulated with GSE for $1 \mathrm{~h}$ in the presence of $100 \mathrm{~mm}-\mathrm{NAC}$ (after pre-incubation with $100 \mathrm{~mm}-\mathrm{NAC}$ for $30 \mathrm{~min}$ ) or in a $\mathrm{Ca}^{2+}$-free NES in the presence of $0.5 \mathrm{~mm}$-EGTA. Then, the same fluorescence analyses were performed after GSE addition. For each experimental condition, eight repetitions were performed in three independent experiments ${ }^{(18)}$.

\section{$\mathrm{Ca}^{2+}$ signalling analysis}

Intracellular $\mathrm{Ca}^{2+}$ content was monitored using the $\mathrm{Ca}^{2+}$ sensitive fluorescent indicator fura-2-acetoxymethyl ester (Molecular Probes), and an inverted Olympus microscope connected to a high-speed wavelength switcher (Polychrome II; TILL Photonics), equipped with a $75 \mathrm{~W}$ stabilised xenon lamp (Ushio, Inc.) and a cooled, charge-coupled device camera (C6790 model; Hamamatsu Photonics). Caco-2 colon cancer cells were plated $\left(5 \times 10^{3}\right.$ cells/well $)$ on specialoptics ninety-six-well plates (Corning Costar) and, after adhesion, loaded with $5 \mu \mathrm{m}$-fura-2-acetoxymethyl ester for $30 \mathrm{~min}$ at $37^{\circ} \mathrm{C}$ in NES, supplemented with $1 \%(\mathrm{w} / \mathrm{v}) \mathrm{BSA}$ The cells were washed twice to remove extracellular dye.

Fura-2-acetoxymethyl ester-loaded cells were sequentially and repetitively excited at 340 and $380 \mathrm{~nm}$. Fluorescence images were acquired with a charge-coupled device camera and stored on an interfaced computer. The acquisition time was one image ratio per $s$. The image ratio calculations were carried out pixel by pixel on a pair of corresponding 340 and $380 \mathrm{~nm}$ image files. Temporal plots (mean value of the fluorescence signal in a selected cellular area) were calculated from the image ratios (340/380). GSE were added during fluorescence acquisition in the standard NES or $\mathrm{Ca}^{2+}$-free NES $\left(\mathrm{CaCl}_{2}\right.$ was substituted by $2 \mathrm{~mm}-\mathrm{MgCl}_{2}$ and $0.5 \mathrm{~mm}$-EGTA was added). For each experimental condition $(100 \mu \mathrm{g} / \mathrm{ml}$ of different GSE, in the presence or absence of EGTA), at least five different wells were analysed ${ }^{(18)}$. The same experiments were performed on HCT- 8 cells.

\section{Western blot}

Caco-2 cells were incubated with $50 \mu \mathrm{g} / \mathrm{ml}$ of Palieri GSE, for 5, 10, $30 \mathrm{~min}, 1$ and $3 \mathrm{~h}$ in (1) a standard medium, (2) the presence of $100 \mathrm{~mm}-\mathrm{NAC}$ after pre-incubation with $100 \mathrm{~mm}-\mathrm{NAC}$ and (3) the $\mathrm{Ca}^{2+}$-free PBS in the presence of $0.5 \mathrm{~mm}$-EGTA. HCT-8 cells were incubated with $50 \mu \mathrm{g} / \mathrm{ml}$ of Palieri GSE, for 5, 10, $30 \mathrm{~min}, 1$ and $3 \mathrm{~h}$ in (1) a standard medium and (2) the presence of $100 \mathrm{~mm}-\mathrm{NAC}$ after pre-incubation with $100 \mathrm{~mm}-\mathrm{NAC}$. Following these treatments, the cells were washed twice with ice-cold PBS and scraped in the following lysis buffer: $50 \mathrm{~mm}$-Tris- $\mathrm{HCl}, \mathrm{pH} 7 \cdot 4, \quad 150 \mathrm{~mm}-\mathrm{NaCl}, 0 \cdot 2 \%$ Nonidet P-40, 1\% CHAPS (3-[(3-Cholamidopropyl)dimethylammonio]-2-hydroxy-1-propanesulfonate) and 2 mm-EDTA dissolved in tetra-distilled water. A mix of protease inhibitors (Complete-Mini Protease Inhibitor Cocktail Tablets; Roche) was added just before use. Cellular extracts were then centrifuged at $14000 \mathrm{rpm}$ for $10 \mathrm{~min}$. The protein content of supernatants was determined using the Bradford assay (Sigma Aldrich). The same protocol was applied to the cells pre-incubated with $100 \mathrm{~mm}-\mathrm{NAC}$ for $30 \mathrm{~min}$ or $0.5 \mathrm{~mm}$-EGTA for $10 \mathrm{~min}$. For immunoblot analyses, $120 \mu \mathrm{g}$ of cellular extracts were separated on SDS-PAGE gels with a concentration of acrylamide specific for the proteins studied. Proteins were blotted onto nitrocellulose membranes (BIO-RAD; Bio-Rad Laboratories) 
and probed with the following antibodies: phospho-ERK1/2 (no. 9106; Cell Signaling Technology, Inc.) and ERK1 (sc-94; Santa Cruz Biotechnology Inc.). Antigens were detected with an enhanced chemoluminescence kit (Amersham Biosciences) according to the manufacturer's instructions. For each data point, three independent experiments were performed.

\section{Statistical analysis}

Results from apoptosis analyses are expressed as means and standard deviations and statistical analysis was performed through ANOVA, followed by the Bonferroni post-test and through unpaired, two-tailed Student's $t$ tests. Data from Western blot densitometry, ROS and mitochondrial membrane potential determinations are expressed as means with their standard errors and statistical analysis was performed through unpaired, two-tailed Student's $t$ tests. Differences were considered as significant at the level of $P<0 \cdot 05$. Statistical analysis was performed using GraphPad Instat software (GraphPad Software, Inc.).

\section{Results}

\section{Reactive oxygen species and $\mathrm{Ca}^{2+}$ mediate grape seed extract-induced apoptosis}

ROS involvement in GSE-mediated apoptosis was assessed on Caco-2 human colon cancer cells. The cells were exposed for 3 and $24 \mathrm{~h}$ to $100 \mu \mathrm{g} / \mathrm{ml}$ of Italia, Palieri or Red Globe GSE in the absence or presence of the antioxidant NAC (100 mM), after pre-incubation of $30 \mathrm{~min}$ with the same $100 \mathrm{~mm}-\mathrm{NAC}$. Then, the cells were analysed by flow cytometry. The GSE concentration of $100 \mu \mathrm{g} / \mathrm{ml}$ was chosen because it was the most effective in inducing the biological effects. Both after 3 and $24 \mathrm{~h}$, Italia, Palieri and Red Globe GSE triggered the apoptosis of Caco-2 colon cancer cells at a significant extent; the presence of NAC strongly inhibited the GSE effect on cell death (Fig. 1(a) and (b)). Furthermore, the participation of $\mathrm{Ca}^{2+}$ mobilisation in GSE-induced cell death was evaluated using the $\mathrm{Ca}^{2+}$ chelator EGTA $(0.5 \mathrm{~mm})$ in an extracellular $\mathrm{Ca}^{2+}$-free medium and exposing the cells to $100 \mu \mathrm{g} / \mathrm{ml}$ of Italia, Palieri or Red Globe GSE for $1 \mathrm{~h}$, before cytometric analysis. The presence of EGTA significantly inhibited the effect of GSE on the Caco-2 apoptotic rate (Fig. 1(c)).

These data suggested that, in Caco-2 colon cancer cells, GSE-induced apoptosis could be mediated by ROS and extracellular $\mathrm{Ca}^{2+}$. Moreover, simultaneous incubation with $\mathrm{NAC}+$ EGTA for $1 \mathrm{~h}$ did not trigger any additive effect on GSEinduced apoptosis, showing results not significantly different with respect to the treatment with NAC or EGTA alone (Fig. 2). These data seem to indicate that in Caco-2 cells, ROS generation and $\mathrm{Ca}^{2+}$ signalling could not act independently of each other in triggering apoptosis.

\section{Grape seed extract triggers an increase in reactive oxygen species production}

Considering the results shown in Fig. 1, we examined whether GSE could trigger intracellular ROS increase, using $\mathrm{H}_{2}$ DCF-DA as a specific ROS probe. In fact, 50 and $100 \mu \mathrm{g} / \mathrm{ml}$ of Italia, Palieri and Red Globe GSE induced a statistically significant increase in ROS levels within the first $10 \mathrm{~min}$ of administration to cell cultures (Fig. 3(a)). Focusing on the lowest concentration $(25 \mu \mathrm{g} / \mathrm{ml})$, only the Palieri GSE-treated samples showed marked ROS production with respect to the control. The presence of the antioxidant NAC blocked the effect induced by GSE on intracellular ROS increase (Fig. 3(b)). After 1 and $3 \mathrm{~h}$ of incubation, no significant differences in ROS levels were detected between the controls and GSE-treated cells (data not shown).

\section{Grape seed extract induces a decrease in mitochondrial membrane potential}

One of the most important hallmarks of apoptosis is the depolarisation of the mitochondrial membrane. In addition, mitochondria are the main source of ROS in the cells ${ }^{(9-11)}$. Thus, we tested the biological effect of GSE on the mitochondrial membrane potential both after a few minutes of treatment and after 1 and $3 \mathrm{~h}$, monitoring the fluorescence emission of JC-1. The results showed that within the first $10 \mathrm{~min}, 25,50$ and $100 \mu \mathrm{g} / \mathrm{ml}$ of Italia and Palieri GSE significantly reduced mitochondrial membrane potential; meanwhile, the Red Globe cultivar showed this effect only at the highest concentration (Fig. 4(a)). After $1 \mathrm{~h}$ of treatment, mitochondrial membrane potential was markedly decreased for all extracts at all the concentrations tested (Fig. 4(b)). At $3 \mathrm{~h}$, only $100 \mu \mathrm{g} / \mathrm{ml}$ of Italia and 50 and $100 \mu \mathrm{g} / \mathrm{ml}$ of Palieri cultivars showed this effect; conversely, Red Globe GSE appeared to revert the effect (Fig. 4(c)).

These results indicate that GSE-induced mitochondrial depolarisation occurred early in the dynamic process of apoptosis.

The administration of $100 \mathrm{~mm}-\mathrm{NAC}$ (after $30 \mathrm{~min}$ pre-incubation with the antioxidant) or $0.5 \mathrm{~mm}$-EGTA in the $\mathrm{Ca}^{2+}$ free medium significantly reverted (even if not completely) the mitochondrial membrane depolarisation induced by GSE after $1 \mathrm{~h}$ incubation (Fig. 5(a) and (b)). These data suggested a possible role of oxidative status and intracellular $\mathrm{Ca}^{2+}$ signalling in the control of mitochondrial membrane potential as well as in apoptotic cell death. Also in this experimental approach, the simultaneous incubation with NAC + EGTA evoked an effect similar to that observed in the treatment with NAC or EGTA alone (Fig. 5(c)). These data seem to indicate that, again, in Caco- 2 cells, ROS generation and $\mathrm{Ca}^{2+}$ signalling could not act independently of each other in triggering mitochondrial depolarisation.

\section{Effects of grape seed extract on $\mathrm{Ca}^{2+}$ signalling}

Since $\mathrm{Ca}^{2+}$ signalling is involved in apoptosis, the modulation of intracellular $\mathrm{Ca}^{2+}$ signalling dynamics in Caco-2 cells was recorded during the administration of $100 \mu \mathrm{g} / \mathrm{ml}$ of GSE to fura-2-loaded cells, using a single-cell approach.

An increase in intracellular $\mathrm{Ca}^{2+}$ was detected after GSE stimulation even if with a different kinetic for each GSE: a rapid and sustained $\mathrm{Ca}^{2+}$ rise induced by Italia GSE, a slower increase induced by Palieri seed extract and a rapid and 
transient increase induced by Red Globe seed extract (Fig. 6(a)-(c), respectively). To determine whether GSEinduced intracellular $\mathrm{Ca}^{2+}$ variations were dependent on extracellular $\mathrm{Ca}^{2+}$ influx, we monitored fura-2-loaded Caco-2 cells during GSE addition in the presence of a $\mathrm{Ca}^{2+}$-free external medium containing $0.5 \mathrm{~mm}$-EGTA. In the Italia and Palieri GSE-treated samples, only 16 or $20 \%$ of the tested cells showed a transient increase in intracellular $\mathrm{Ca}^{2+}$ (Fig. 6(d) and (e)). Red Globe GSE failed to induce any intracellular $\mathrm{Ca}^{2+}$ variations in the presence of extracellular EGTA (Fig. 6(f)).
These data indicated that Italia and Palieri GSE promote both extra- and intracellular $\mathrm{Ca}^{2+}$ mobilisation; meanwhile, Red Globe GSE primarily triggers extracellular $\mathrm{Ca}^{2+}$ uptake.

\section{Grape seed extract-induced modulation of extracellular signal-regulated kinase/mitogen-activated protein kinase protein}

Considering that GSE-induced apoptosis may be mediated by both $\mathrm{ROS}$ and $\mathrm{Ca}^{2+}$, we investigated some related signalling
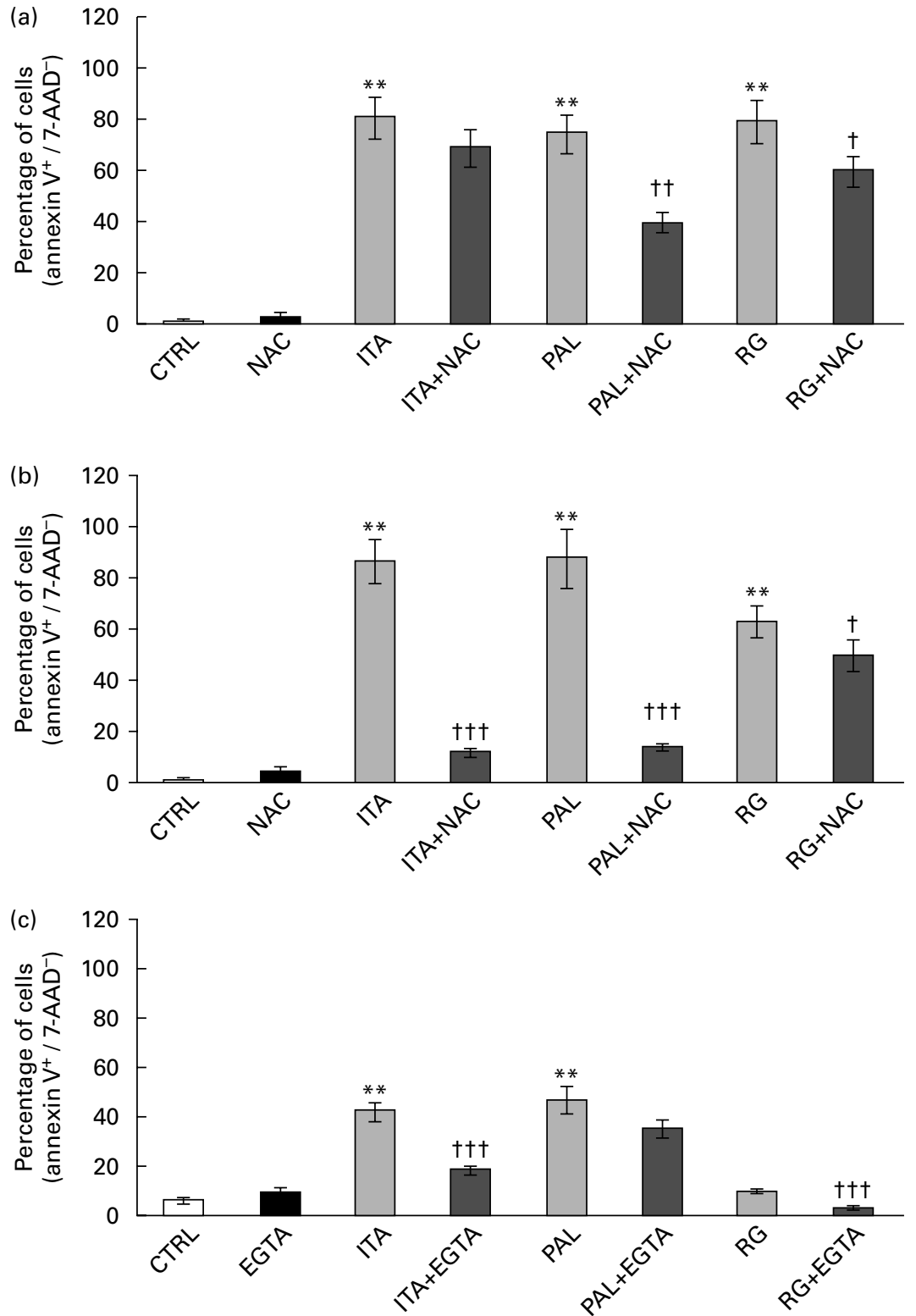

Fig. 1. Grape seed extract (GSE)-induced apoptosis in Caco-2 cells occurs via reactive oxygen species and $\mathrm{Ca}^{2+}$ involvement. Pretreatment with $\mathrm{N}$-acetyl cysteine (NAC, $100 \mathrm{~mm}$ ) inhibited GSE-induced apoptosis after (a) $3 \mathrm{~h}$ and (b) $24 \mathrm{~h}$ exposure to $100 \mu \mathrm{g} / \mathrm{ml}$ of Italia (ITA), Palieri (PAL) or Red globe (RG) GSE. The presence of ethylene glycol tetraacetic acid (EGTA, $0.5 \mathrm{~mm}$ ) inhibited GSE-induced apoptosis after (c) $1 \mathrm{~h}$ exposure to $100 \mu \mathrm{g} / \mathrm{ml}$ of ITA, PAL or RG GSE. The percentage of apoptotic cells (annexin $\mathrm{V}^{+} / 7$-aminoactinomycin (AAD) ${ }^{-}$), obtained through flow cytometry, is reported. Values are means of three independent experiments, with standard deviations represented by vertical bars. ${ }^{\star *}$ Mean value was significantly different compared with the control condition by ANOVA, followed by Bonferroni post-test $(P<0.01)$. Mean values were significantly different between the GSE-treated cells and GSE + NAC- or GSE + EGTA-treated cells by unpaired, two-tailed Student's $t$ test: $\dagger P<0.05$; †† $P<0.01$; †† $P<0.001$. CTRL, control. 
Fig. 2. No additive effect on the apoptosis inhibition of $N$-acetyl cysteine (NAC) + ethylene glycol tetraacetic acid (EGTA) $v$. NAC or EGTA alone. Simultaneous $1 \mathrm{~h}$ pretreatment with NAC $(100 \mathrm{~mm})$ and EGTA $(0.5 \mathrm{~mm})$ of $100 \mu \mathrm{g} / \mathrm{ml}$ of grape seed extract-stimulated Caco-2 cells did not induce an additive effect on the decreasing apoptotic rate with respect to NAC or EGTA alone. The percentage of apoptotic cells (annexin $\mathrm{V}^{+} / 7$-aminoactinomycin $(\mathrm{AAD})^{-}$), obtained through flow cytometry, is reported. Values are means of three independent experiments, with standard deviations represented by vertical bars. CTRL, control; ITA, Italia; PAL, Palieri; RG, Red Globe.

events induced by GSE in Caco- 2 cells. In particular, the response of ERK/MAPK, a molecule sensitive and responsive to extracellular stimuli, was measured. Indeed, MAPK represent one of the major connection points among apoptosis, ROS and $\mathrm{Ca}^{2+}$ signalling ${ }^{(11,12)}$. We monitored, in a time course analysis from 0 to $3 \mathrm{~h}$, ERK phosphorylation and activation in the presence of $50 \mu \mathrm{g} / \mathrm{ml}$ of Palieri GSE, which proved to be the most effective cultivar in inducing Caco-2 cell death, as well as ROS production and mitochondrial membrane depolarisation. The $50 \mu \mathrm{g} / \mathrm{ml}$ GSE was chosen because cells treated with $100 \mu \mathrm{g} / \mathrm{ml}$ underwent massive apoptosis, making it difficult to recover viable samples for immunoblot analyses. ERK was strongly dephosphorylated in the presence of GSE (Fig. 7).

The presence of $100 \mathrm{~mm}-\mathrm{NAC}$ (after a $30 \mathrm{~min}$ pretreatment with the same NAC concentration) significantly inhibited the Palieri effect on ERK inactivation (Fig. 8). Moreover, Caco-2 stimulation by GSE in the $\mathrm{Ca}^{2+}$-free medium and in the presence of $0.5 \mathrm{~mm}$-EGTA resulted in a significant increase in
ERK/MAPK phosphorylation, showing the lack of the GSE-induced effect (Fig. 8).

Taken together, these data suggested that ERK is involved in ROS- and $\mathrm{Ca}^{2+}$-mediated apoptosis triggered by GSE.

\section{Grape seed extract effects on other colon cells}

In order to assess whether GSE could exert its effects on other colon cells, we treated HCT-8 cancer cells and primary human normal colon fibroblasts with GSE. GSE-induced apoptosis has previously been reported for HCT-8, while the same effect was not present on colon fibroblasts ${ }^{(19)}$. In the present study, ROS involvement in GSE-mediated apoptosis was assessed on both human colon cancer HCT-8 cells and normal primary human colon fibroblasts. The cells were exposed for $3 \mathrm{~h}$ to $100 \mu \mathrm{g} / \mathrm{ml}$ of Italia, Palieri or Red Globe GSE in the absence or presence of the antioxidant NAC $(100 \mathrm{~mm})$, after pre-incubation of $30 \mathrm{~min}$ with the same $100 \mathrm{~mm}-\mathrm{NAC}$. Then, the cells were analysed by flow cytometry. After $3 \mathrm{~h}$, Italia, Palieri and
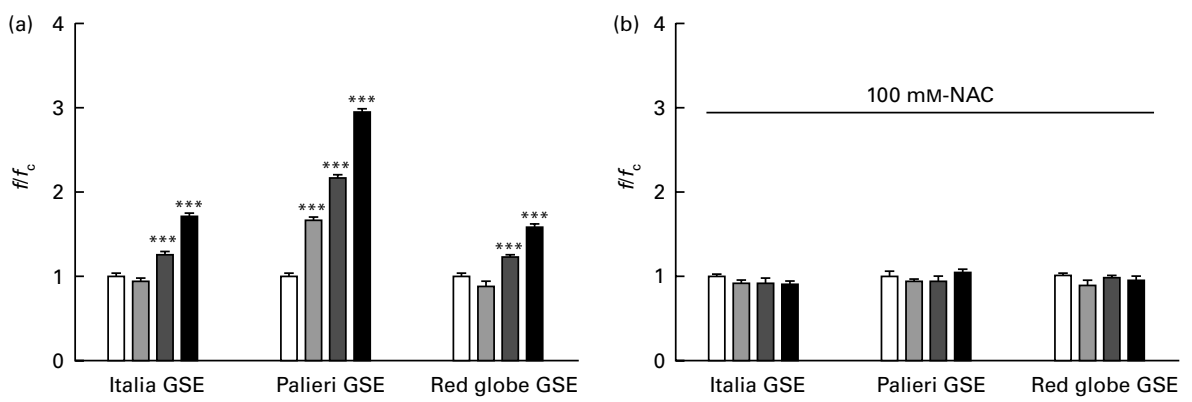

Fig. 3. Dose-dependent reactive oxygen species (ROS) generation in Italia, Palieri and Red Globe grape seed extract (GSE)-treated Caco-2 cells (a) without and (b) with $\mathrm{N}$-acetyl cysteine (NAC, $100 \mathrm{~mm}$ ). After incubating with dichlorodihydrofluorescein diacetate, the cells were rinsed with normal external solution and exposed to $25 \mu \mathrm{g} / \mathrm{ml}(\square), 50 \mu \mathrm{g} / \mathrm{ml}(\square)$ and $100 \mu \mathrm{g} / \mathrm{ml}(\square)$ of GSE for $10 \mathrm{~min}$. The amount of intracellular ROS was estimated by using a microplate reader measuring fluorescence intensity at $490-520 \mathrm{~nm}$. Data are expressed as fold increase with respect to the control ( $\square$ ). For each experimental condition, eight repetitions were performed in three independent experiments. Values are means, with their standard errors represented by vertical bars. ${ }^{\star \star \star}$ Mean value was significantly different compared with the control conditions by unpaired, two-tailed Student's $t$ test $(P<0.001)$. $f$, Fluorescence value acquired in the treated samples; $f_{c}$, fluorescence value acquired in the unexposed control samples. 

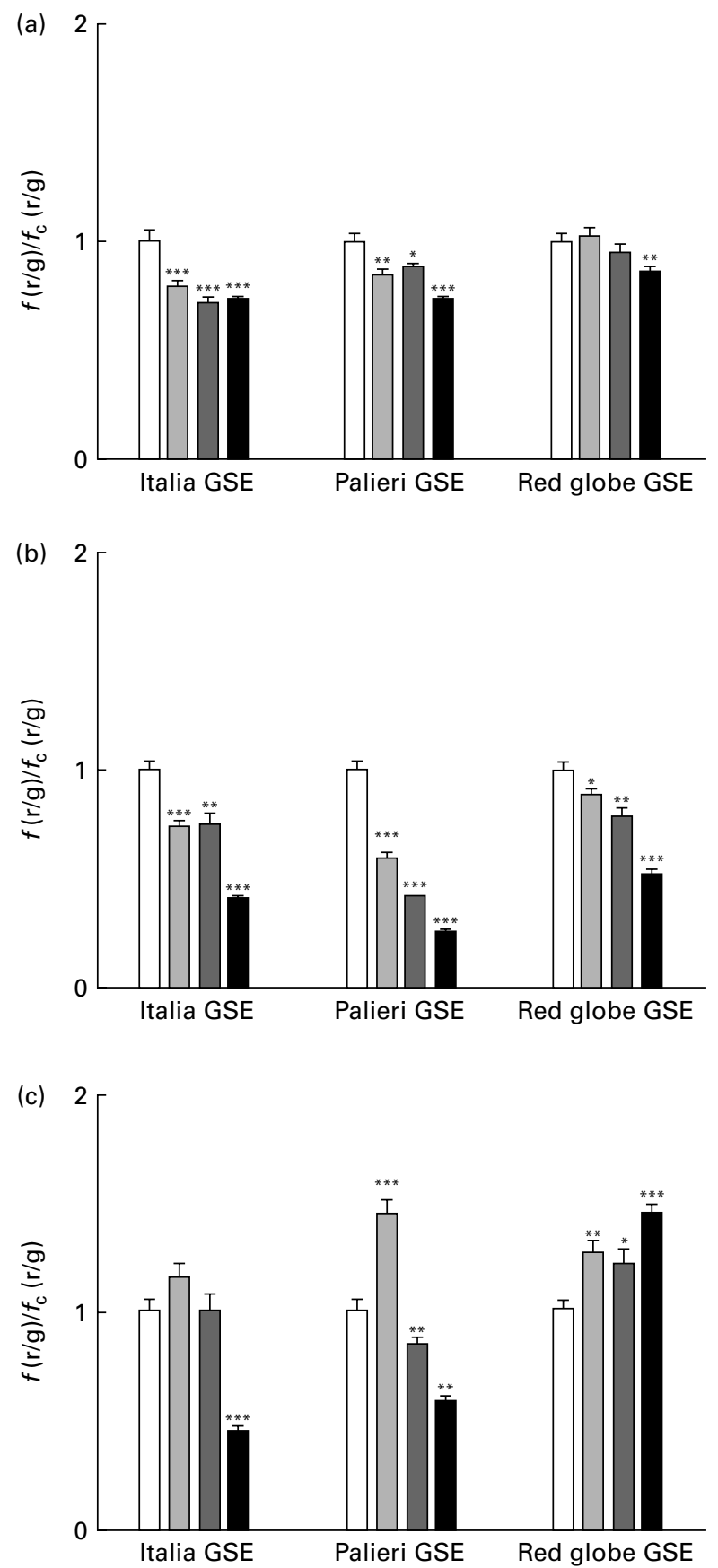

Fig. 4. Decrease in the mitochondrial membrane potential induced by Italia Palieri and Red Globe grape seed extract (GSE) in Caco-2 cells in terms of dose and time response. The cells were incubated with GSE $(25 \mu \mathrm{g} / \mathrm{ml}(\square)$,

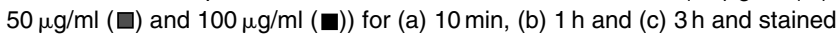
with $5,5^{\prime}, 6,6^{\prime}$-tetrachloro-1, $1^{\prime}, 3,3^{\prime}$ - tetraethylbenzimidazolylcarbocyanine iodide/chloride (JC-1). The fluorescence of loaded cells was detected using an excitation wavelength of $485 \mathrm{~nm}$ and recording the emissions of the JC-1 monomer and aggregate at 530 and $590 \mathrm{~nm}$, respectively. Data are expressed as fold increase with respect to the control. Eight repetitions were performed for each experimental condition in three independent experiments. Values are means, with their standard errors represented by vertical bars. Mean values were significantly different compared with the control conditions by unpaired, two-tailed Student's $t$ test: ${ }^{*} P<0.05 ; \quad{ }^{* *} P<0.01 ; \quad{ }^{* \star *} P<0.001 . \quad f(r / g)$, red:green fluorescence value acquired in the treated samples; $f_{c}(r / g)$, red: green fluorescence value acquired in the unexposed control $(\square)$ samples.
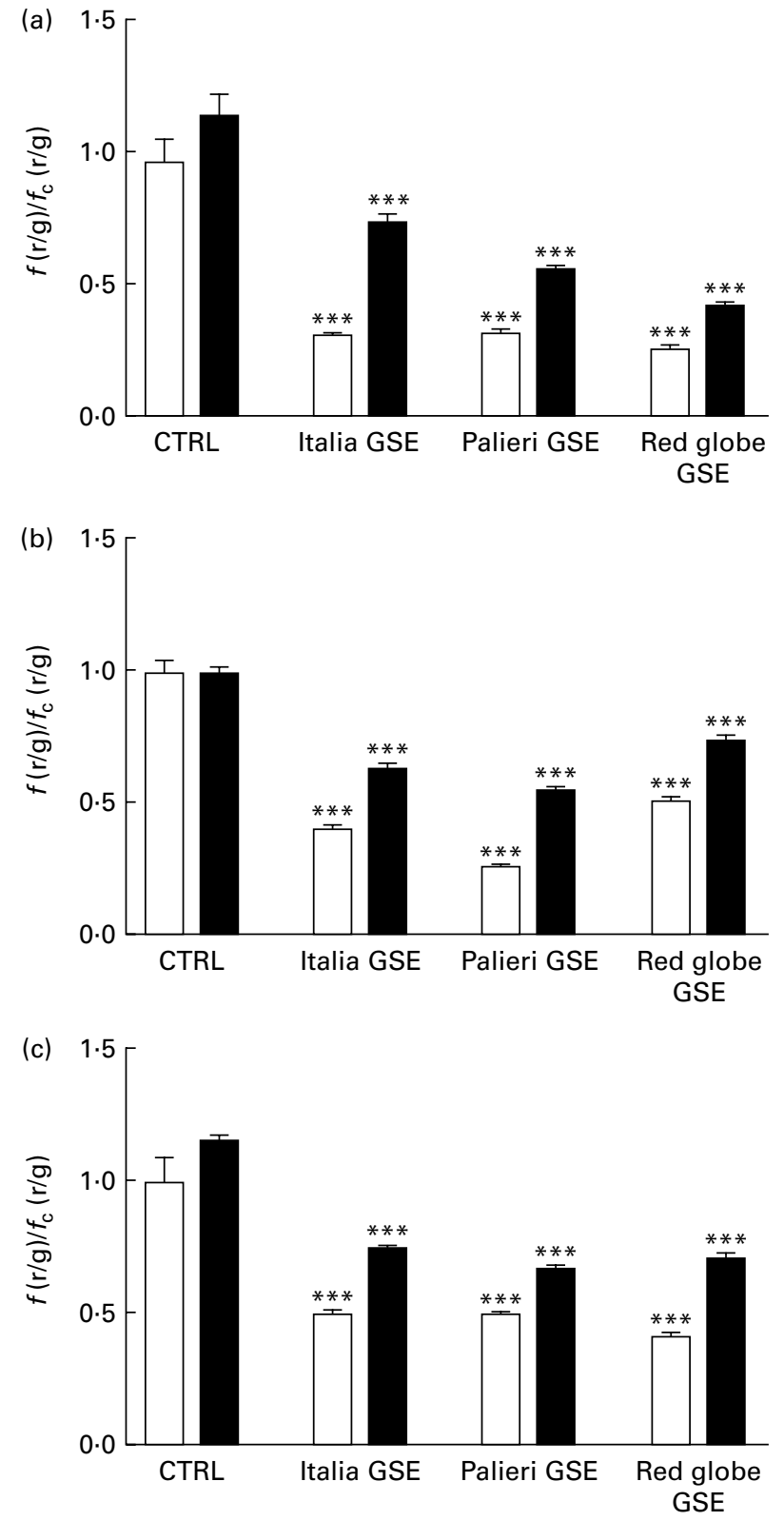

Fig. 5. Italia, Palieri and Red Globe grape seed extract (GSE)-induced mitochondrial membrane depolarisation in Caco-2 cells involves reactive oxygen species and intracellular $\mathrm{Ca}^{2+}$. Pre-incubation with (a) $\mathrm{N}$-acetyl cysteine (NAC; - NAC ( $\square)$; + NAC ( $\square)$ ) (100 mM) or (b) the presence of ethylene glycol tetraacetic acid (EGTA; -EGTA ( $\square$ ); + EGTA (ם)) $(0.5 \mathrm{mM})$ decreases the mitochondrial membrane depolarisation induced by $100 \mu \mathrm{g} / \mathrm{ml}$ of GSE after $1 \mathrm{~h}$ incubation. The presence of (c) NAC + EGTA $(\boldsymbol{D})$ is not able to completely revert the effect induced by GSE. After the exposure to GSE, Caco-2 cells were stained with 5,5',6,6'-tetrachloro$1,1^{\prime}, 3,3^{\prime}$-tetraethylbenzimidazolylcarbocyanine iodide/chloride (JC-1). $\square$, None. The fluorescence of loaded cells was detected using an excitation wavelength of $485 \mathrm{~nm}$ and recording the emissions of the JC-1 monomer and aggregate at 530 and $590 \mathrm{~nm}$, respectively. Eight repetitions were performed for each experimental condition in three independent experiments. Values are means, with their standard errors represented by vertical bars. *** Mean value was significantly different compared with the control (CTRL) conditions by unpaired, two-tailed Student's $t$ test $(P<0.001)$. $f(r / g)$, red:green fluorescence value acquired in the treated samples; $f_{\mathrm{c}}(\mathrm{r} / \mathrm{g})$, red:green fluorescence value acquired in the unexposed CTRL samples. 

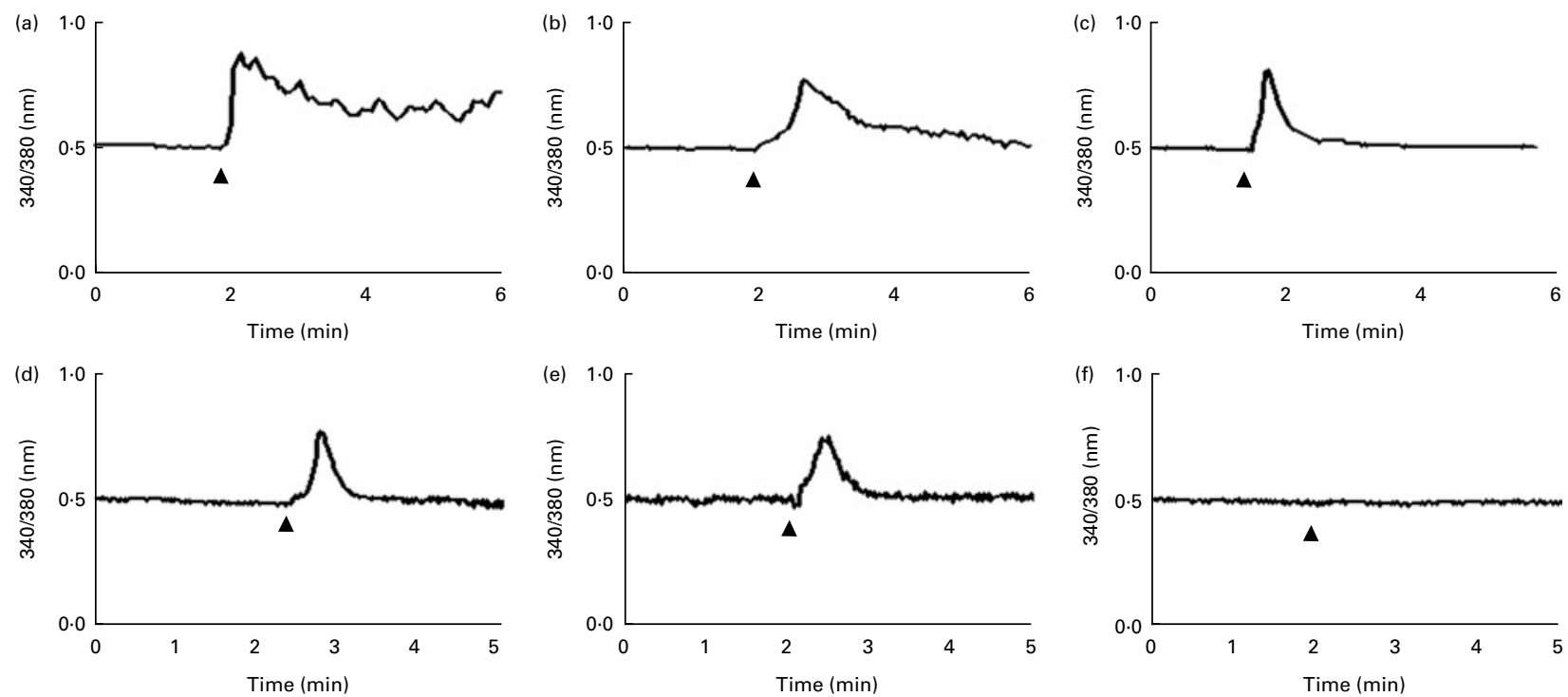

Fig. 6. Grape seed extract (GSE) induces intracellular $\mathrm{Ca}^{2+}$ increase in Caco-2 cells. After loading with fura-2-acetoxymethyl ester $(5 \mu \mathrm{M})$, the cells, seeded on special-optics ninety-six-well plates, were excited at 340 and $380 \mathrm{~nm}$ and exposed to $100 \mu \mathrm{g} / \mathrm{ml}$ of (a) Italia (responsive cells, $100 \%$; tested cells, $n 52$ ), (b) Palieri (responsive cells, $100 \%$; tested cells, $n 45$ ) and (c) Red Globe (responsive cells, $100 \%$; tested cells, $n 36$ ) GSE. In the presence of EGTA (0.5 mM) and Ca ${ }^{2+}$-free medium, (d) Italia (responsive cells, $16 \%$; tested cells, $n$ 70) and (e) Palieri (responsive cells, $20 \%$; tested cells, $n$ 121) GSE showed a transient increase in intracellular $\mathrm{Ca}^{2+}$ only in 16 and $20 \%$ of the cell population, respectively. (f) Red Globe (responsive cells, $0 \%$; tested cells, $n$ 51) GSE did not induce any intracellular $\mathrm{Ca}^{2+}$ variations. For each experimental condition, at least five different wells were analysed.

Red Globe GSE triggered the apoptosis of HCT-8 colon cancer cells at a significant extent; the presence of NAC strongly inhibited the GSE effect on cell death (Fig. 9(a)). On the other hand, the viability of normal primary human colon fibroblasts was unmodified by the GSE treatment with respect to the control cultures (Fig. 10(a)).

The HCT- 8 treatment with 25,50 and $100 \mu \mathrm{g} / \mathrm{ml}$ of Italia, Palieri and Red Globe GSE induced, within the first $10 \mathrm{~min}$, a dose-dependent ROS increase (Fig. 9(b)). The same experiment was performed on normal primary human colon fibroblasts, and no significant ROS increase was detected in the GSE-treated cells with respect to the control cultures (Fig. 10(b)).

No increase in intracellular $\mathrm{Ca}^{2+}$ was detected after GSE stimulation in HCT-8 cells (Fig. 9(c)). Moreover, in these cells, after $3 \mathrm{~h}$ of incubation with $50 \mu \mathrm{g} / \mathrm{ml}$ of Palieri GSE, ERK was strongly dephosphorylated with respect to the untreated cells, and the addition of NAC completely reverted the GSE effect on ERK inactivation (Fig. 9(d)).

\section{Discussion}

Despite the increasing understanding of processes and mechanisms in colonic carcinogenesis, current therapies, including surgery, chemotherapy, radiotherapy and molecular-targeted therapy, are still of limited benefit in advanced tumours. Hence, a growing amount of scientific attention has been focused on investigating the potential role of dietary substances for both the prevention and control of colon cancer through chemopreventive strategies ${ }^{(20)}$. Epidemiological studies have shown that fruit and vegetable consumption may correlate with the decreased risk of colon cancer ${ }^{(21,22)}$. Namely, grape fruits as well as grape-derived beverages (wine) have received much attention as preventive nutraceuticals ${ }^{(23)}$. Indeed, GSE is rich in flavonoids, and exhibits a broad spectrum of pharmacological properties: antioxidant, free radical-scavenging, antiinflammatory, anti-carcinogenic, anti-viral, anti-bacterial, anti-thrombogenic and anti-atherogenic activities ${ }^{(20)}$.

It is of utmost importance that GSE triggers apoptosis in Caco-2 cells via caspase-dependent and -independent

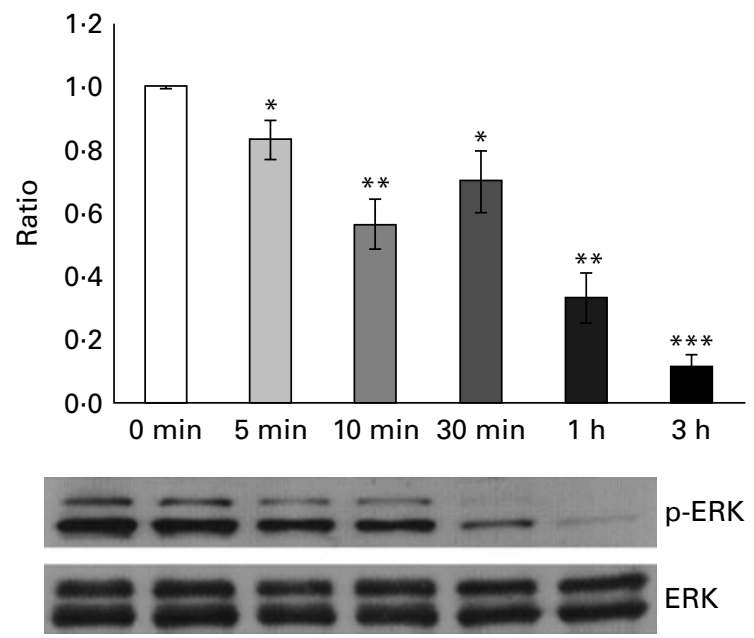

Fig. 7. Palieri grape seed extract (GSE) decreases extracellular signal-regulated kinase (ERK)/mitogen-activated protein kinase phosphorylation $(p)$ in Caco- 2 cells. Cells were exposed to GSE $(50 \mu \mathrm{g} / \mathrm{ml})$ in a time course from 0 to $3 \mathrm{~h}$. Cells were harvested at different time points and cell lysates were prepared to determine the phosphorylated and total protein levels of ERK, using Western blot analysis. Values are means (three independent experiments) of the ratio between the optical density (OD) of the p-ERK band in the GSEtreated samples and the OD of the untreated control cell band $(0 \mathrm{~min})$, with their standard errors represented by vertical bars. Mean values were significantly different compared with the control condition by unpaired, two-tailed Student's $t$ test: ${ }^{*} P<0.05 ;{ }^{* *} P<0.01 ;{ }^{* \star} P<0.001$. 

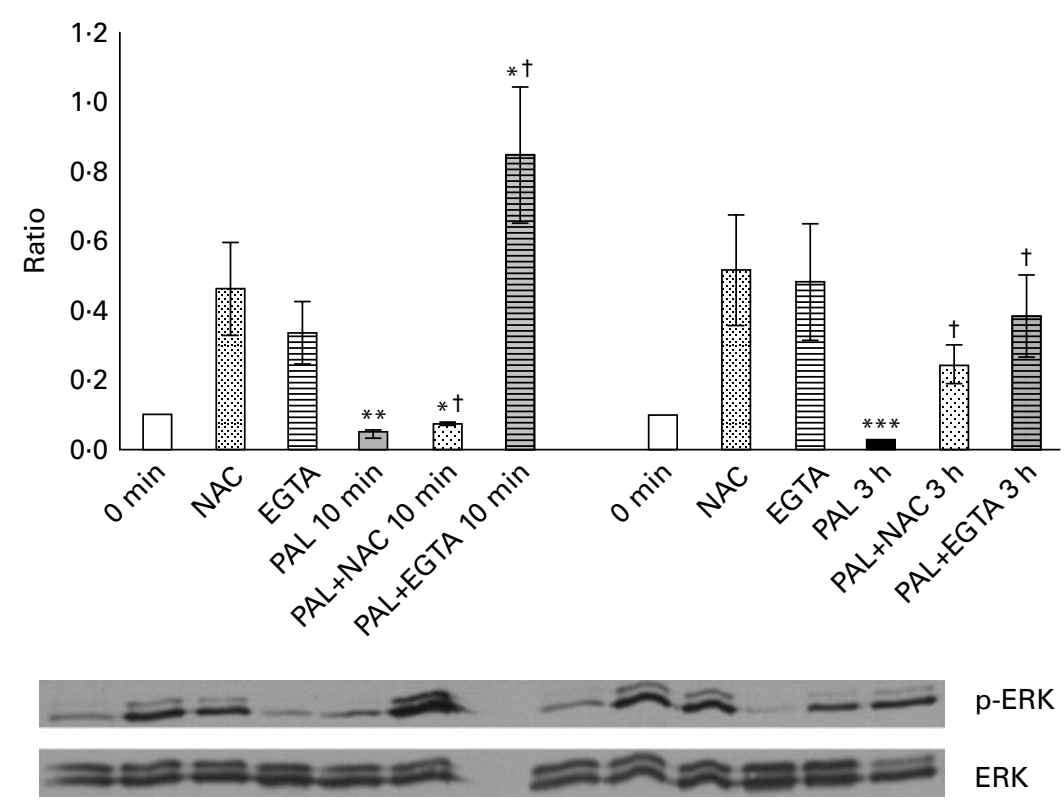

Fig. 8. Palieri (PAL) grape seed extract (GSE) decreases extracellular signal-regulated kinase phosphorylation ( $p$-ERK) via reactive oxygen species and intracellular $\mathrm{Ca}^{2+}$ mobilisation in Caco-2 cells. Cells were exposed to GSE $(50 \mu \mathrm{g} / \mathrm{ml}$ ) with or without pretreatment with $\mathrm{N}$-acetyl cysteine (NAC, $100 \mathrm{~mm})$ or the presence of ethylene glycol tetraacetic acid (EGTA, $0.5 \mathrm{~mm}$ ) for $10 \mathrm{~min}$ and $3 \mathrm{~h}$. Cells were harvested at different time points and cell lysates were prepared to determine the phosphorylated and total protein levels of ERK, using Western blot analysis. Values are means (three independent experiments) of the ratio between the optical density (OD) of the p-ERK band in the NAC, EGTA, GSE and GSE + NAC or GSE + EGTA samples and the OD of the untreated control cells band $(0 \mathrm{~min})$, with their standard deviations represented by vertical bars. Mean values were significantly different compared with the control condition by unpaired, two-tailed Student's $t$ test: ${ }^{*} P<0.05 ;{ }^{\star *} P<0.01 ;{ }^{* \star} P<0.001$. † Mean value was significantly different between the PAL GSE-treated cells and the PAL + NAC or PAL + EGTA-treated cells by unpaired, two-tailed Student's $t$ test $(P<0.05)$.

pathways $^{(8)}$; the mechanisms culminating in apoptotic cell death remain still unclear, though. We hypothesised that ROS and $\mathrm{Ca}^{2+}$ influx could probably participate in such a mechanism.

Changes in the intracellular level of ROS have been reported to play an important role in the early step of apoptosis, anticipating loss of the mitochondrial membrane potential and release of those apoptotic-inducing factors, such as cytochrome $c$ and activated caspases ${ }^{(24)}$. Broad evidence has proved that drug-induced ROS production is responsible for apoptosis in different types of cancer such as cervical ${ }^{(25)}$, pancreatic $^{(26)}$, gastric ${ }^{(27)}$, breast ${ }^{(28)}$ as well as colon cancer and leukaemia ${ }^{(29,30)}$.

In our cell model, Caco-2 cells, Italia, Palieri and Red Globe GSE also significantly increased ROS production, in a dosedependent manner, within a few minutes of treatment. A GSE-induced ROS increase is a determinant partner in triggering cell apoptosis. As a proof of principle, addition of NAC, a well-known ROS scavenger, hampers ROS release and significantly decreases GSE-induced apoptosis.

The mitochondrial transmembrane potential is often used as an indicator of cellular viability, and metabolic activity, and its disruption has been involved in a variety of apoptotic phenomena ${ }^{(31)}$. Moreover, mitochondria have also been implicated in ROS generation during apoptosis. Indeed, reduced mitochondrial membrane potential has recently been shown to lead to increased generation of ROS and apoptosis ${ }^{(32,33)}$. In Caco-2 cells, Italia, Palieri and Red Globe GSE induced a time- and dose-dependent mitochondrial membrane depolarisation, mainly after about $1 \mathrm{~h}$ of treatment.

Also in this case, pre-incubation with NAC significantly decreased GSE effects on mitochondria, supporting the hypothesis of the tight linkage between these organelles and the redox system.

The temporal analysis of GSE-induced effects leads to the speculation that ROS generation, observed within the first minutes of exposure, could participate, together with other signals, in the GSE-induced cellular pathway(s), as one of the first steps that, in turn, triggered mitochondrial membrane depolarisation, reaching its highest effect at $1 \mathrm{~h}$ of incubation.

Furthermore, mitochondria are central players in cellular $\mathrm{Ca}^{2+}$ signalling by shaping and buffering cellular $\mathrm{Ca}^{2+}$ signals ${ }^{(34,35)}$. It is widely recognised that $\mathrm{Ca}^{2+}$ displays growthinhibiting and differentiation-promoting activities in a variety of normal and malignant epithelial cells, including cells of the gastrointestinal tract ${ }^{(36)}$. In the present experiment, intracellular $\mathrm{Ca}^{2+}$ rapidly increased after the addition of GSE to the culture. This effect might be due to the mobilisation of intracellular $\mathrm{Ca}^{2+}$ stores, or to the influx of extracellular $\mathrm{Ca}^{2+}$. In order to address these issues, Caco-2 cells were incubated in a $\mathrm{Ca}^{2+}$-free medium containing the $\mathrm{Ca}^{2+}$ chelator EGTA. Interestingly, by chelating $\mathrm{Ca}^{2+}$ in the culture medium, in the Red Globe-treated cells, intracellular concentration of $\mathrm{Ca}^{2+}$ was unchanged, showing that, in this very case, modification in intracellular $\mathrm{Ca}^{2+}$ was tightly dependent on extracellular $\mathrm{Ca}^{2+}$ influx. On the contrary, addition of EGTA to the medium reduced but did not completely inhibit 

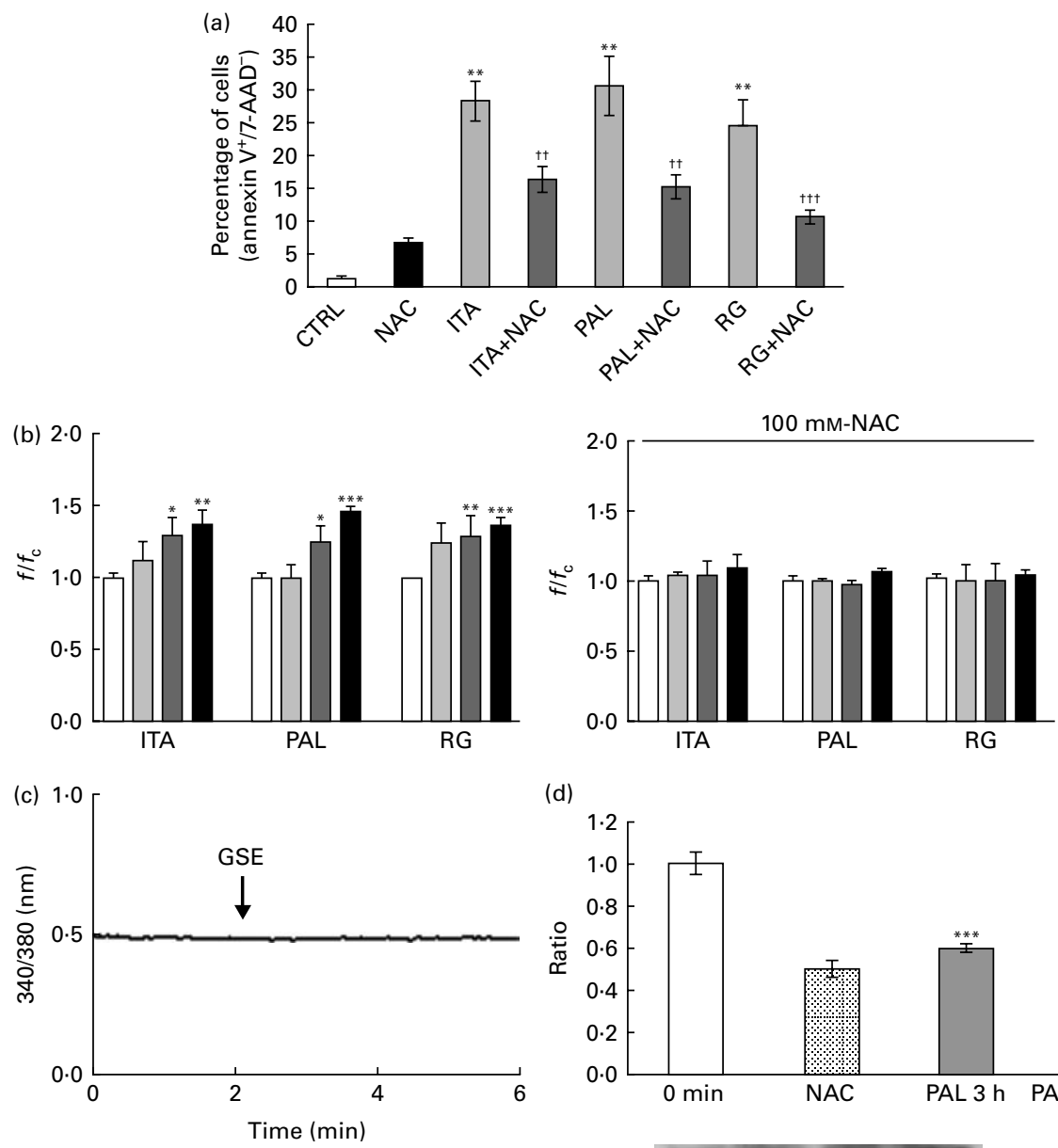

(d)

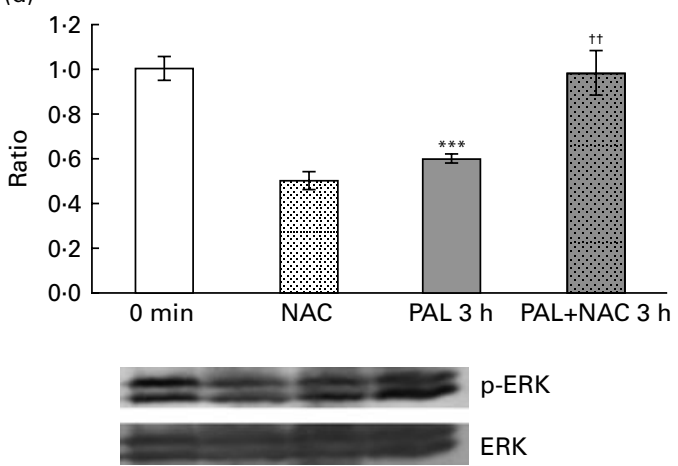

Fig. 9. Grape seed extract (GSE) effects on HCT-8 cells. (a) $100 \mu \mathrm{g} / \mathrm{ml}$ of GSE-induced apoptosis after $3 \mathrm{~h}$ of exposure, in the absence or presence of $N$-acetyl cysteine (NAC, $100 \mathrm{~mm}$ ). The percentage of apoptotic cells (annexin $\mathrm{V}^{+} / 7$-aminoactinomycin (AAD) $)^{-}$), obtained through flow cytometry, is reported. Values are means of three independent experiments, with standard deviations represented by vertical bars. ${ }^{* \star}$ Mean value was significantly different compared with the control condition by ANOVA, followed by Bonferroni post-test $(P<0.01)$. Mean values were significantly different between the GSE-treated cells and the GSE + NAC-treated cells by unpaired, two-tailed Student's $t$ test: $\dagger \dagger P<0.01$; $\dagger_{\dagger} P<0.001$. (b) Dose-dependent reactive oxygen species (ROS) generation in the Italia (ITA), Palieri (PAL) and Red Globe (RG) GSE-treated HCT-8 cells without and with NAC (100 mM), assayed by means of dichlorodihydrofluorescein diacetate. Data are expressed as fold increase with respect to the control. For each experimental condition, eight repetitions were performed in three independent experiments. Values are means, with standard deviations represented by vertical bars. Mean values were significantly different compared with the control conditions by unpaired, two-tailed Student's $t$ test: ${ }^{*} P<0.05 ;{ }^{\star \star} P<0.01$; ${ }^{\star \star \star} P<0.001$. $\square$, Control (CTRL); $\square, 25 \mu \mathrm{g} / \mathrm{ml}$; $\square, 50 \mu \mathrm{g} / \mathrm{ml} ; \mathbf{\square}, 100 \mu \mathrm{g} / \mathrm{ml}$. (c) GSE failed in inducing an intracellular $\mathrm{Ca}^{2+}$ increase in HCT-8 cells, monitored using fura-2-acetoxymethyl ester $(5 \mu \mathrm{M})$. Total tested cells were as follows: forty-five ITA GSE-treated cells; sixty-seven PAL GSE-treated cells; fifty-three RG GSE-treated cells. (d) $50 \mu \mathrm{g} / \mathrm{ml}$ PAL GSE decreases extracellular signal-regulated kinase phosphorylation ( $p$-ERK) via ROS in HCT-8 cells, assayed by Western blot analysis. values are means (three independent experiments) of the ratio between the optical density $(\mathrm{OD})$ of the p-ERK band in the NAC, GSE and GSE + NAC samples and the OD of the untreated control cells (CTRL) band (0 min), with their standard errors represented by vertical bars. ${ }^{* * *}$ Mean value was significantly different compared with the control condition by unpaired, two-tailed Student's $t$ test $(P<0 \cdot 001)$. †† Mean value was significantly different between the PAL GSE-treated cells and the PAL + NAC-treated cells by unpaired, two-tailed Student's $t$ test $(P<0.01)$. $f$, Fluorescence value acquired in the treated samples; $f_{\mathrm{c}}$, fluorescence value acquired in the unexposed control samples.

the increase observed in $\mathrm{Ca}^{2+}$ intracellular levels, thus demonstrating that $\mathrm{Ca}^{2+}$ release after the treatment with Palieri- and Italia-derived GSE is partly due to the depletion of intracellular $\mathrm{Ca}^{2+}$ stores. These results suggest that different grape cultivars exert selective biological effects on $\mathrm{Ca}^{2+}$ physiology. In turn, $\mathrm{Ca}^{2+}$ shows to be essential for inducing apoptosis. Indeed, the $\mathrm{Ca}^{2+}$-free medium (after adding EGTA) significantly inhibited GSE-induced apoptosis as well as mitochondrial depolarisation, thus suggesting the two phenomena are entrenched.
The different chemical composition of each grape extract could probably explain the differences observed in their molecular effects ${ }^{(15)}$.

Moreover, the simultaneous incubation with NAC and EGTA did not trigger any additive effect on apoptosis or mitochondrial depolarisation modulated by GSE. As reported by Feissner et al. ${ }^{(37)}$, a crosstalk signalling between $\mathrm{Ca}^{2+}$ and ROS exists. In fact, ROS may regulate the activity of $\mathrm{Ca}^{2+}$-activated channels and, at the same time, increased $\mathrm{Ca}^{2+}$ levels could promote ATP synthesis-induced ROS generation. In our model, ROS 
generation and $\mathrm{Ca}^{2+}$ signalling did not appear to act independently of each other in triggering apoptosis and mitochondrial depolarisation. In fact, inhibiting both ROS and $\mathrm{Ca}^{2+}$ signalling, an additive biological response was not observed.

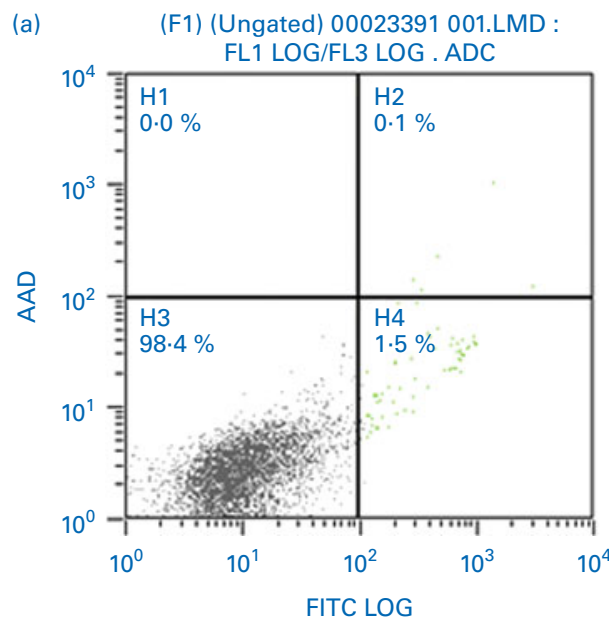

(c)

(F1) (Ungated) 00023393 001.LMD : FL1 LOG/FL3 LOG . ADC

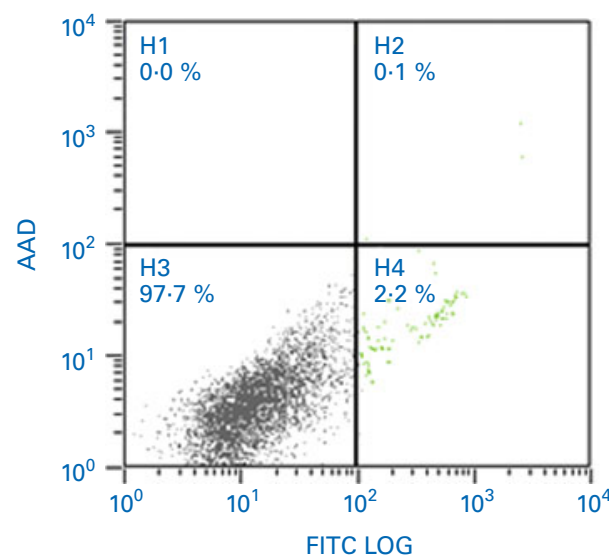

As previously discussed ${ }^{(8,19)}$, GSE contains several molecules with a pyrogallol-type structure that can exert anticancer activity. Palieri GSE showed the highest concentration of compounds provided by a pyrogallol-type structure ${ }^{(13)}$, and,

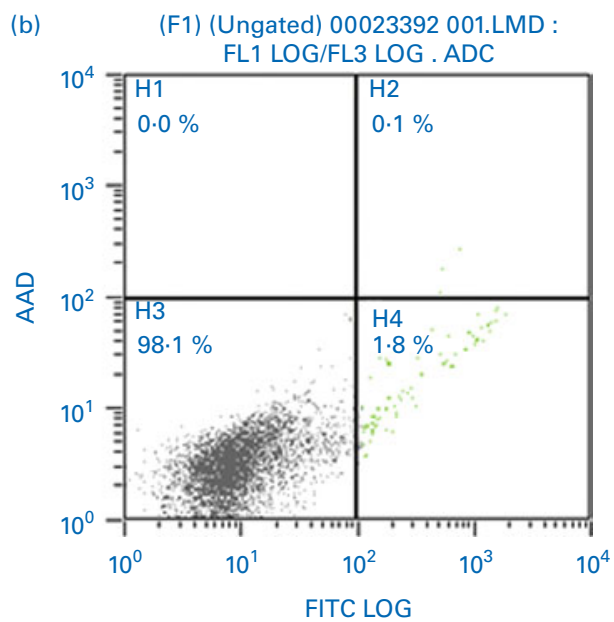

(d)

(F1) (Ungated) 00023395 001.LMD : FL1 LOG/FL3 LOG. ADC

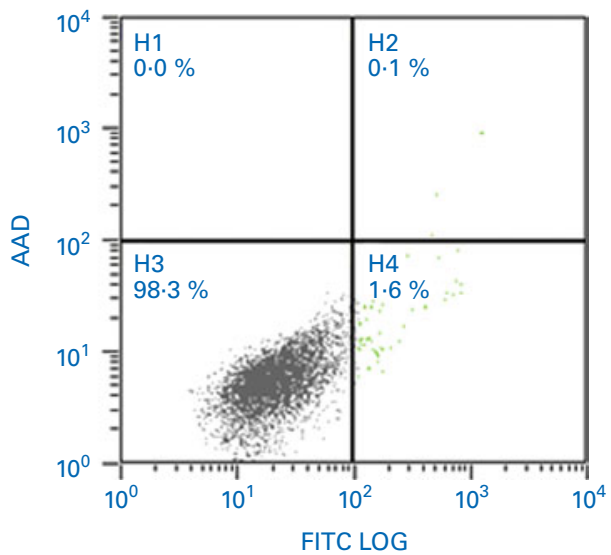

(e) 1.8

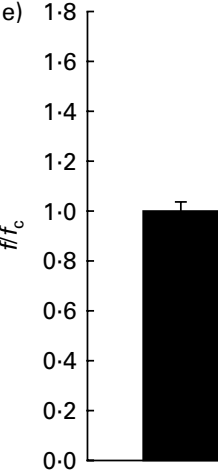

CTRL

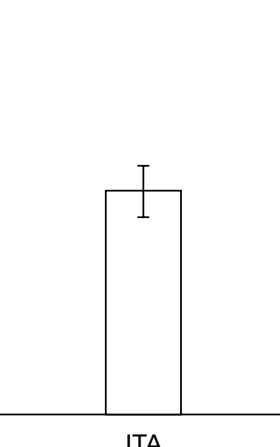

ITA

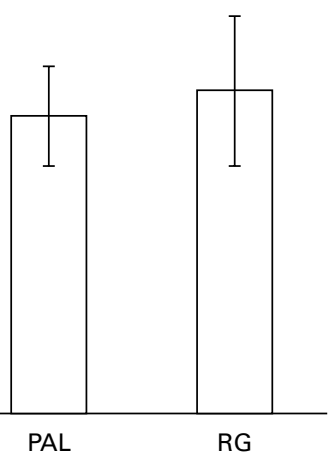

Fig. 10. Grape seed extract (GSE) effects on normal primary human colon fibroblasts. $100 \mu \mathrm{g} / \mathrm{ml}$ of GSE ((a) control, (b) Italia, (c) Palieri and (d) Red Globe) did not induce apoptosis in normal primary human colon fibroblasts. Dual-parameter flow cytometric density dot plots for the GSE-treated cells. Fluorescence intensity for annexin V-fluorescein isothiocyanate (FITC) is plotted on the $x$-axis and 7-aminoactinomycin-D (AAD) is plotted on the $y$-axis. The lower left quadrant cells (annexin $\mathrm{V}^{-} / 7-\mathrm{AAD}^{-}$) were defined as viable cells, the lower right quadrant cells (annexin $\mathrm{V}^{+} / 7-\mathrm{AAD}^{-}$) as apoptotic cells and the upper right quadrant cells (annexin $\mathrm{V}^{+} / 7-\mathrm{AAD}^{+}$) as late apoptotic cells. (e) GSE failed to induce reactive oxygen species increase in normal primary human colon fibroblasts, assayed by means of dichlorodihydrofluorescein diacetate. Data are expressed as fold increase with respect to the control (CTRL). For each experimental condition, eight repetitions were performed in three independent experiments. ITA, Italia; PAL, Palieri; RG, Red Globe. (A colour version of this figure can be found online at http:// www.journals.cambridge.org/bjn). 
as expected, the highest apoptotic rate, as well as ROS production and mitochondrial membrane depolarisation, were recorded in the Palieri-treated cells. Therefore, we focused on the Palieri cultivar, investigating the signalling involved in Palieri GSE-induced cell death.

Stress conditions and extracellular $\mathrm{Ca}^{2+}$ are both known to activate by phosphorylation members of the MAPK family, namely $\mathrm{ERK}^{(38,39)}$. Promotion of survival through ERK phosphorylation has been documented by many studies. Data presented herein supported this assumption, given that ERK resulted in significant dephosphorylation, and hence inactivated in the presence of Palieri GSE. Interestingly, pretreatment with NAC almost completely reversed GSE-mediated ERK inactivation, hence showing that ROS induction is mandatory to activate ERK. Moreover, by adding NAC to Palieri-treated cancer cells, we demonstrated a significant apoptosis decrease. These results highlight the link among intracellular ROS increase and the subsequent induction of GSE-mediated apoptosis.

Changes in $\mathrm{Ca}^{2+}$ fluxes exert altogether a relevant contribution to GSE-mediated apoptosis, through the modulation of ERK activation. Addition of EGTA reduces $\mathrm{Ca}^{2+}$ influx, allowing ERK phosphorylation, and eventually contributes to the cell survival. Thus, both ROS induction and increased intracellular $\mathrm{Ca}^{2+}$ levels converge to foster ERK inactivation and programmed cell death after GSE treatment, as exemplified in Fig. 11.

GSE-induced apoptosis has been reported not only for Caco-2 cells. As previously reported ${ }^{(19)}$, GSE induced apoptosis in HCT-8 cells in a dose- and time-dependent manner. Herein, we demonstrated that GSE-induced HCT-8 apoptosis is a ROS-mediated process, considering the increase in ROS levels and the inhibition of apoptosis after NAC incubation. ROS are probably involved in ERK dephosphorylation and inactivation, as demonstrated by the increase in the phospho-ERK:ERK ratio after NAC incubation. Differently from Caco-2, in HCT-8 cells, GSE-induced apoptosis did not involve

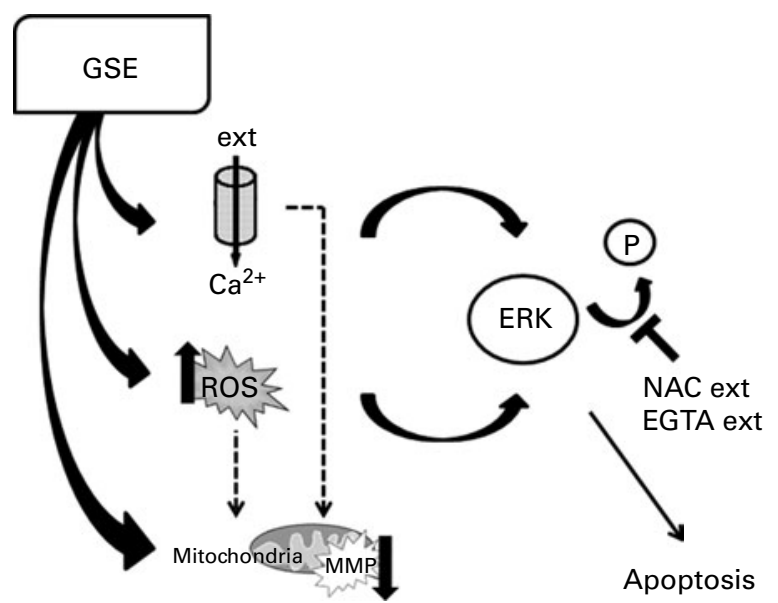

Fig. 11. Schematic representation of grape seed extract (GSE)-mediated effects on Caco-2 cells. ext, Extracellular; P, phosphate group; ERK, extracellular signal-regulated kinase; NAC, N-acetyl cysteine; EGTA, ethylene glycol tetraacetic acid; ROS, reactive oxygen species; MMP, mitochondria membrane potential. intracellular $\mathrm{Ca}^{2+}$ mobilisation, as no intracellular $\mathrm{Ca}^{2+}$ increase was recorded after GSE addition.

Interestingly, a significant increase neither in ROS levels nor in apoptotic rate was observed in normal primary human colon fibroblasts, to which GSE was added. These results indicated that the GSE effect is cell-specific, depending on the cell phenotype: normal or cancer cells. The partial difference in GSE-mediated apoptotic signalling could be probably due to the biologically different sensitivity of cell lines from the same cancer type, such as Caco- 2 and HCT-8 cells.

In conclusion, the present results show that in Caco-2 human colon cancer cells, GSE generated ROS and promoted extracellular $\mathrm{Ca}^{2+}$ uptake, hence inducing mitochondrial membrane depolarisation and apoptosis. These effects involve at least an ERK-mediated pathway, leading to the inactivation of ERK and related survival processes. Relevance of such mechanism could easily explain the increased interest for GSE-related compounds in a clinical cancer setting.

\section{Acknowledgements}

No funding was received for the present study. All authors have no personal or financial conflicts of interest and they have not entered into any agreement that could interfere with our access to the data on the research or on our ability to analyse the data independently, to prepare manuscripts and to publish them. S. D. and M. A. M. designed and performed the experiments, analysed the data and wrote the manuscript. C. M. and S. G. performed some experiments and analysed the data. A. C. contributed to the design of the experiments and gave conceptual advice. A. P., F. D'A. and S. P. contributed to the performance of the experiments and the analysis of the data. P. C. performed the cytofluorimetric analysis. M. B. supervised the experiments and wrote the manuscript.

\section{References}

1. Janakiram NB \& Rao CV (2008) Molecular markers and targets for colorectal cancer prevention. Acta Pharmacol Sin 29, 1-20.

2. Bruce WR, Giacca A \& Medline A (2000) Possible mechanisms relating diet and risk of colon cancer. Cancer Epidemiol Biomarkers Prev 9, 1271-1279.

3. Cooke D, Steward WP, Gescher AJ, et al. (2005) Anthocyans from fruit and vegetables: does bright colour signal cancer chemopreventive activity? Eur J Cancer 41, 1931-1940.

4. Clifton PM (2004) Effect of grape seed extract and quercetin on cardiovascular and endothelial parameters in high-risk subjects. J Biomed Biotechnol 2004, 272-278.

5. Surh YJ (2003) Cancer chemoprevention with dietary phytochemicals. Nat Rev Cancer 3, 768-780.

6. Bagchi D, Bagchi M, Stohs SJ, et al. (2000) Free radicals and grape seed proanthocyanidin extract: importance in human health and disease prevention. Toxicology 148, 187-197.

7. Katiyar SK (2008) Grape seed proanthocyanidines and skin cancer prevention: inhibition of oxidative stress and protection of immune system. Mol Nutr Food Res 52, S71-S76.

8. Dinicola S, Cucina A, Pasqualato A, et al. (2010) Apoptosisinducing factor and caspase-dependent apoptotic pathways 
triggered by different grape seed extracts on human colon cancer cell line Caco-2. Br J Nutr 104, 824-832.

9. Thannickal VJ \& Fanburg BL (2000) Reactive oxygen species in cell signaling. Am J Physiol Lung Cell Mol Physiol 279, L1005-L1028.

10. Torres M \& Forman HJ (2003) Redox signaling and the MAP kinase pathways. Biofactors 17, 287-296.

11. Chen KC, Liu WH, Kao PH, et al. (2010) Calcium-stimulated mitogen-activated protein kinase activation elicits $\mathrm{Bcl}-\mathrm{xL}$ downregulation and Bak upregulation in notexin-treated human neuroblastoma SK-N-SH cells. J Cell Physiol 222, $177-186$.

12. Hsu WH, Hsieh YS, Kuo HC, et al. (2007) Berberine induces apoptosis in SW620 human colonic carcinoma cells through generation of reactive oxygen species and activation of JNK/ p38 MAPK and FasL. Arch Toxicol 81, 719-728.

13. Wilankar C, Khan NM, Checker R, et al. (2011) $\gamma$-Tocotrienol induces apoptosis in human $\mathrm{T}$ cell lymphoma through activation of both intrinsic and extrinsic pathways. Curr Pharm Des 17, 2176-2189.

14. Kim JY, Yu SJ, Oh HJ, et al. (2011) Panaxydol induces apoptosis through an increased intracellular calcium level, activation of JNK and p38 MAPK and NADPH oxidase-dependent generation of reactive oxygen species. Apoptosis 16, 347-358.

15. Cavaliere C, Foglia P, Gubbiotti R, et al. (2008) Rapidresolution liquid chromatography/mass spectrometry for determination and quantitation of polyphenols in grape berries. Rapid Commun Mass Spectrom 22, 3089-3099.

16. Wang H \& Joseph JA (1999) Quantifying cellular oxidative stress by dichlorofluorescein assay using microplate reader. Free Radic Biol Med 27, 612-616.

17. Morabito C, Rovetta F, Bizzarri M, et al. (2010) Modulation of redox status and calcium handling by extremely low frequency electromagnetic fields in $\mathrm{C} 2 \mathrm{C} 12$ muscle cells: a real-time, single-cell approach. Free Radic Biol Med 48, 579-589.

18. Mariggiò MA, Falone S, Morabito C, et al. (2010) Peripheral blood lymphocytes: a model for monitoring physiological adaptation to high altitude. High Alt Med Biol 11, 333-342.

19. Dinicola S, Cucina A, Pasqualato A, et al. (2012) Antiproliferative and apoptotic effects triggered by grape seed extract (GSE) versus epigallocatechin and procyanidins on colon cancer cell lines. Int J Mol Sci 13, 651-664.

20. Pan MH, Lai CS, Wu JC, et al. (2011) Molecular mechanisms for chemoprevention of colorectal cancer by natural dietary compounds. Mol Nutr Food Res 55, 32-45.

21. Michels KB, Giovannucci E, Chan AT, et al. (2006) Fruit and vegetable consumption and colorectal adenomas in the Nurses' Health Study. Cancer Res 66, 3942-3953.

22. Kune G \& Watson L (2006) Colorectal cancer protective effects and the dietary micronutrients folate, methionine, vitamins $\mathrm{B}_{6}, \mathrm{~B} 12, \mathrm{C}, \mathrm{E}$, selenium, and lycopene. Nutr Cancer 56, 11-21.

23. Chao C, Slezak JM, Caan BJ, et al. (2008) Alcoholic beverage intake and risk of lung cancer: the California Men's Health Study. Cancer Epidemiol Biomarkers Prev 17, 2692-2699.
24. Teo IT, Tang JC, Chui CH, et al. (2004) Superoxide anion is involved in the early apoptosis mediated by Gleditsia sinensis fruit extract. Int J Mol Med 13, 909-913.

25. Lin YT, Yang JS, Lin SY, et al. (2008) Diallyl disulfide (DADS) induces apoptosis in human cervical cancer Ca Ski cells via reactive oxygen species and $\mathrm{Ca}^{2+}$-dependent mitochondria dependent pathway. Anticancer Res 28, 2791-2799.

26. Zhang R, Humphreys I, Sahu RP, et al. (2008) In vitro and in vivo induction of apoptosis by capsaicin in pancreatic cancer cells is mediated through ROS generation and mitochondrial death pathway. Apoptosis 13, 1465-1478.

27. Qian X, Li J, Ding J, et al. (2008) Glibenclamide exerts an antitumor activity through reactive oxygen species-c-jun NH2-terminal kinase pathway in human gastric cancer cell line MGC-803. Biochem Pharmacol 76, 1705-1715.

28. Xiao D, Powolny AA \& Singh SV (2008) Benzyl isothiocyanate targets mitochondrial respiratory chain to trigger reactive oxygen species-dependent apoptosis in human breast cancer cells. J Biol Chem 283, 30151-30163.

29. Pan MH, Gao JH, Lai CS, et al. (2008) Antitumor activity of 3,5,40-trimethoxystilbene in COLO 205 cells and xenografts in SCID mice. Mol Carcinog 47, 184-196.

30. Feng R, Ni HM, Wang SY, et al. (2007) Cyanidin-3-rutinoside, a natural polyphenol antioxidant, selectively kills leukemic cells by induction of oxidative stress. J Biol Chem $\mathbf{2 8 2}$, 13468-13476.

31. Marchetti P, Castedo M, Susin SA, et al. (1996) Mitochondrial permeability transition is a central coordinating event of apoptosis. J Exp Med 184, 1155-1160.

32. Zamzami N, Marchetti P, Castedo M, et al. (1995) Sequential reduction of mitochondrial transmembrane potential and generation of reactive oxygen species in early programmed cell death. J Exp Med 182, 367-377.

33. Finkel T \& Holbrook NJ (2000) Oxidants, oxidative stress and the biology of ageing. Nature 408, 239-247.

34. Eager KR, Roden LD \& Dulhunty AF (1997) Actions of sulfhydryl reagents on single ryanodine receptor $\mathrm{Ca}(2+)$-release channels from sheep myocardium. Am J Physiol 272, C1908-C1918.

35. Boitier E, Rea R \& Duchen MR (1999) Mitochondria exert a negative feedback on the propagation of intracellular $\mathrm{Ca}^{2+}$ waves in rat cortical astrocytes. J Cell Biol 145, 795-808.

36. Lamprecht SA \& Lipkin M (2003) Chemoprevention of colon cancer by calcium, vitamin D and folate: molecular mechanisms. Nat Rev Cancer 3, 601-614.

37. Feissner RF, Skalska J, Gaum WE, et al. (2009) Crosstalk signaling between mitochondrial $\mathrm{Ca}^{2+}$ and ROS. Front Biosci 14, 1197-1218.

38. Martindale JL \& Holbrook NJ (2002) Cellular response to oxidative stress: signaling for suicide and survival. $J$ Cell Physiol 192, 1-15.

39. Bhagavathula N, Kelley EA, Reddy M, et al. (2005) Upregulation of calcium-sensing receptor and mitogenactivated protein kinase signalling in the regulation of growth and differentiation in colon carcinoma. Br J Cancer 93, 1364-1371. 